\title{
TANATOLOGIKE VLADANA DESNICE - IGRE POETIKE I SMRTI
}

\section{Bojan Jović}

UDK: 821.163.42Desnica, V.:612.013

Izvorni znanstveni članak

Sažetak: U radu se istražuju vidovi oblikovanja tematsko-motivskog kompleksa bolesti, umiranja i smrti u opusu Vladana Desnice, u koji je uključena i problematika samoubistva, nasilnog okončanja života, mogućnosti lečenja i iskorenjivanja bolesti, i postizanja besmrtnosti. Navedena tematika, i u delima u kojima to nije vidljivo na prvi pogled, podrazumeva dvojstvo uzvišenog i niskog, misaonog i materijalnog / telesnog, ozbiljnog i humorno-ironičnog, skladnog i grotesknog. Navedene osobine, praćene otvorenošću i nedovršenošću tekstova, polifonim spajanjem romana sa esejistikom, poezije sa prozom, pustolovine sa apstraktnim razmišljanjem, eksplicitne sa implicitnom poetikom, uz umetanje manjih žanrova, upućuju na prisustvo osobina tradicije ozbiljno-smešne / karnevalizovane književnosti. Stoga se naznačava važnost istraživanja genealoške perspektive smehovnog i karnevalizovanog uobličavanja problema bolesti i smrti kao jedan od mogućih ključeva za obuhvatno i slojevito tumačenje Desničinog književnog dela. ${ }^{1}$

Ključne reči: Vladan Desnica, tematika smrti, žanrovi ozbiljno-smešne književnosti, karnevalizacija, groteska

(...) osjećaja života koji me je, makar i nespoznat, neprepoznat, makar $i$ prerušen u svoju suprotnost, u igru poigravanja s ništavilom, u žed samouništenja, kroz čitav život vitlao i pratio.

Vladan Desnica, Proljeća Ivana Galeba

D ela Vladana Desnice sadrže brojna mesta tematizacije fenomena (ljudske) smrt(nost)i, koja se u nekolikim prilikama razvijaju u šire, zaokružene celine, poput refleksivnog, patetikom obojenog poglavlja XIX romana Proljeća Ivana Galeba. U navedenom poglavlju iznose se zapažanja o smrti kao temeljnom, neprestano prisutnom i određujućem fenomenu ljudskog bivstvovanja, koji predstavlja osnovnu, možda i jedinu, filozofsku i umetničku temu. Misao (o) smrti, dalje, nije dana svima, već pripada samo izabranima

1 Rad je nastao u okviru naučnog projekta Instituta za književnost i umetnost iz Beograda ON178008 Srpska književnost u evropskom kulturnom kontekstu, koji finansira Ministarstvo prosvete, nauke i tehnološkog razvoja Republike Srbije. 
- za nju je potrebna stvaralačka fantazija, budući da što je veći čovek to je veća i njegova smrt: „s ponekim umiru čitave galaksije“.2 Suprotstavljanje smrti je „revolt, to je borba, to je akcija“. Nadalje: „To je podvig. Najviša akcija i vrhovni podvig: borba za nemoguće. To je prometejstvo. “3 Poglavlje se završava navođenjem prevedenih stihova iz Eshilovog Okovanoga Prometeja koji, po mišljenju Desničinog junaka Ivana Galeba, predstavljaju „najvišu pjesničku (a i ljudsku) riječ koja je ikad rečena: Da nisi možda još i dalje drznuo? / Smrtniku uskratih da sagleda svoj kraj. / A kakav li mu lijek za to nađe ti? / Njegovu grud napučih slijepim nadama. / O, blagodat si silnu dao čovjeku!“4

Navedeno poglavlje, međutim, ima i svoj pandan u poglavlju XL, koje predstavlja otklon i svojevrsni samokritično-ironični komentar prethodno iznesenih stavova. U njemu se najpre, kao uznošenje, samodopadljivost i loš ukus, odbacuje kontemplacija smrti, kao i intimizacija sa smrću, koja je obično prati - kozerija i koketerija, da bi se, na kraju, sa čovekomumetnikom konačno javila i neprihvatljiva stilizacija smrti, njen umetnički preobražaj. Ivan Galeb daje i konkretan primer takve stilizacije u obliku provizornog, kič i farsičnog scenarija za balet u kome kostimirana smrt, vitlajući kosom, progoni druge likove, mladića i devojku. Sve ove manifestacije čovekovog misaonog i umetničkog uobličavanja smrti, međutim, postaju ništavne u trenutku stvarnog suočavanja sa bolešću ili umiranjem, u kome jedinka, zaboravljajući na razmišljanja o kosmosu i ljudskoj vrsti, ostaje ogoljena i sama.

Upravo ovo dvojstvo, koje odslikava, problematizuje i izokreće iskazano, nagoveštava jednu od bitnih crta Desničinog književnog postupka: razvijanje i sučeljavanje suprotnosti. Ozbiljnom i patetičnom se kod Desnice suprotstavlja šaljivo i ironijsko; unutrašnjem i kontemplativnom - spoljašnje i materijalno / telesno; mladom, životnom i zdravom - staro umorno i bolesno; strogoj (ili, pak, „strogoj“) refleksiji - farsični umetnički igrokaz, itd. Desnica neprekidno relativizuje i podriva iskaze svojih junaka, pripoved(a)nih iskaza, pa čak i teksta u celini, polifonijskim naslojavanjima značenja odnosno dijaloškim sučeljavanjima, ili pak, namernim protivurečnostima, omaškama i izostavljanjima izvođenja logičkih posledica iznesenih mišljenja, čineći to ili neposredno ili naknadno, sa odloženim dejstvom.

Ovakav pristup, dat u daleko drastičnijem i sniženijem registru, možda je najupečatljivije prisutan u nevelikom Desničinom ranom radu, u tekstu Nobelovac, označenom kao „humoreska“, u kome slavni pisac i Nobelov laureat Norbert Bruk na jednom mestu razmišlja o svom romanu u nastajanju, naslovljenom I pojest će vas djeca vaša. Brukov slojeviti unutrašnji dijalog, iskazan kroz pripovedanje u trećem licu, u više tokova živo pretresa nekolika moguća rešenja raspleta. Početno otkrivanje mrtvog tela oskrnavljene devojčice menja se u scenu u kojoj nju deda davi zbog „greha“, odnosno u potonje detetovo ubijanje dede sekirom po zatiljku, praćeno naglašeno grotesknim detaljima (starčevo volujsko samrtničko mukanje; šakali pod stolom rskaju kosti; krv koja šiklja do plafona pretvarajući se najpre u vodoskok, potom i u pravu poplavu), korenitom promenom okolnosti (ubistvo iz afekta / straha zbog dedinog besa pokazuje se zapravo kao ubistvo s predumišljajem) te

\footnotetext{
Vladan Desnica, Proljeća Ivana Galeba, Beograd 1982., 77.

Isto, 78 .

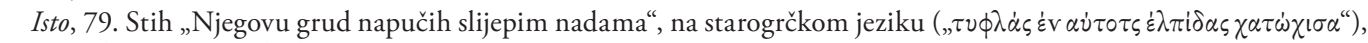
stoji i kao moto poglavlja.
} 
još grotesknijim piščevim „kritičkim“ komentarima (nalaženje silovane i ubijene devojčice u staničnom lavabou jeste „Zahvalno“ ali previše „naturalističko“; rešenje sa kasapljenjem dede je „već bolje“, „dobro“, „od-lič-no“).5

Ispostavlja se, dalje, da je Brukov roman u nastajanju u potpunoj opreci s njegovom uobičajenom javnom pozom (opštečovečanski izraz, vidovit pogled „preko glava savremenika, u zamagljeno krilo budućnosti“) i sa uvek istim visokoparnim kič govorima koje drži, što značenje Desničinog teksta u celini usložnjava, dodajući mu i element svojevrsne strukturne ironije. ${ }^{6}$ Ona se, naknadno, uočava i u napetosti između žanrovske oznake rada i samoga teksta, budući da „humoreska“ podrazumeva vrstu novele i kratke priče koja se „odlikuje vedrinom humora, veselošću i jednostavnošću obrade“, ona „uvek zadržava zabavan ton i predstavlja svoju sadržinu u optimističkom, šaljivom svetlu“,7 što je sasvim udaljeno od Desničinog složenog štiva i u osnovi tamnog i grotesknog humora. „Humoreska“ Nobelovac tako ubedljivo pokazuje da se već u ran(ij)oj fazi Desničinog stvaralaštva, osim već pomenutih, u zgusnutom vidu javljaju i drugi elementi bitni za njegovu poetiku - pre svega nezaobilazna tematizacija fenomena (ljudske) smrt(nost)i u mnogo neposrednijem vidu, s izrazitim prisustvom grotesknog i šokantnog, jedenje / proždiranje i komadanje tela u prenosnom (I pojest će vas djeca vaša), asocijativno-slikovitom (šakali) i doslovnom (udaranje sekirom) smislu, kao i naročiti odnos tela i prostora (tj. širenje telesnih sastojaka u prostor - poplava krvi). ${ }^{8}$

U dosadašnjim razmatranjima Desničinog opusa navedene osobine sporadično su dovođene u vezu s osobinama žanrova ozbiljno-smešnog i karnevalizacije, ${ }^{9}$ naročite književne tradicije koja je u evropskoj istoriji književnosti prisutna od njenih početaka, a koju je

5 „Sinu mu mogućnost jednog novog rješenja: kako bi bilo - umjesto da malu Moniku, prerano razvijeno i nervno istančano jedanaestogodišnje siroče o djedovoj brizi, nađu silovanu i umorenu u kolodvorskom 'lavabou' (što bi doduše bilo zahvalno, ali malko previše naturalističko) - kako bi bilo, umjesto toga, da sam djed, impulzivan do neuračunljivosti, saznavši za djetinji 'grijeh', zadavi nesretno dijete?... Ne, ni to ne valja! - Ili možda (da, da, to je već bolje!) da dijete, u ludom strahu pred djedovim bijesom kad dozna cijelu stvar, iskoristi momenat, dok joj on za stolom dotjeruje domaću zadaću, pa ga šine sjekiricom po zatiljku?... Da, to će biti dobro! (Pred očima mu počeše spremno nicati detalji: starome od udarca vrče naočali preko stola, i kasnije, pod nogama susjeda koji pritrče na njegovo volujsko samrtničko mukanje, stakla tih naočala jezivo krčkaju, kao da šakali pod stolom rskaju kosti; pojedinosti su nicale dalje - na prvi nesiguran udarac starac se podupire dlanovima o sto i pokušava se okrenuti, našto mala - ne više zato da ga usmrti, nego naprosto iz straha da ne sagleda njegove zakovrnute oči i da učini kraj tom njegovom nepodnosivom mukanju - nastavlja da udara, gotovo mehanički, sve brže i sve jačim zamasima; a zatim, kad se već umorila, opazi da je krv šiknula do stropa, visoko po zidovima, vidje se u nemogućnosti da ispere i ukloni tragove, kao što je u prvi mah bila naivno smislila, i učini joj se kao da se nalazi posred bujnog, nepresušenog vodoskoka krvi, u poplavi krvi koja raste i raste, koja ju je svu opkolila, od koje je već obnevidjela...) Da, da, tako će biti odlično, od-lič-no!“ Vladan Desnica, „Nobelovac“, Ilustrirani vjesnik (Zagreb), br. 184, 5. 3. 1949., 12. Još jedan primer kod Desnice izuzetno retkog uživljavanja u svest ubice može se naći u rukopisu nedovršene drame Gadni mali gnom, u liku Dr Petjoa, serijskog ubice Jevreja tokom Drugog svetskog rata. Videti: Vladan DesnicA, „Gadni mali gnom“, Republika, 64/2008., br. 3-4, 3-21.

6 „Jutros, (za riječju se dobro osjećao zarez)... Jutros, čim sam izišao iz stanice, pogled mi je pao na dvije figure vaših seljanki s korpama divnoga voća: u bistrom jutarnjem zraku nezagađenu dimom iz fabričkih dimnjaka, stasite i mirne, one mi se prividiše kao dvije karijatide koje stražare na ulazu u neku bajoslovnu baštu prepunu sočnih plodova zemlje..."V. Desnica, „Nobelovac“, 12.

7 Rečnik književnih termina (gl. ur. Dragiša Živković), Beograd 1992., 274.

8 Takođe, krajnje retki motivi telesnog erotizma podrazumevaju spoj nasilja i pervertirane seksualnosti, poput prigušene, posredno prikazane pedofilske epizode u pripoveci Spiriti. Up. Vladan Desnica, „Spiriti“, Književnost, 9/1954., br. 7-8, 78-79.

9 Vladimir Biti, Doba svjedočenja. Tvorba identiteta u suvremenoj hrvatskoj prozi, Zagreb 2005., $135-171$. 
svojim istraživanjima u prvi plan stavio Mihail Bahtin. ${ }^{10} \mathrm{U}$ tome svetlu, u ovom radu će se istaći samo neke osobenosti umetničkog postupka Vladana Desnice vezanog za tanatopoetiku, onako kako se, upućujući na prisustvo osnovnih elemenata iz navedene tradicije, na najupečatljivije načine protežu kroz različite oblasti i žanrove njegovog dela. U središtu pažnje naći će se za smrt vezano preplitanje različitih vrsta prostora / područja - psihološkog, fizičkog, estetskog i društvenog, utemeljeno na (humorno / ironičnom) suprotstavljanju, variranju i inverziji naročitih motiva odnosa duševno / duhovno - telesno, dete - čovek, pojedinac - grupa, narod - država; pri tome će se naglasak staviti na sinoptički sinhronijski pregled, bez nastojanja da se podrobno prikaže hronologija / dinamika odnosno žanrovske specifičnosti navedenih postupaka / osobenosti u okviru Desničine poetike / opusa.

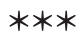

Razmatranje smrti kod Desnice polazi od unutrašnjeg doživljaja - pitanju smrti (jedinke) najpre se pristupa kao unutarnjem, najšire psihološkom problemu, koji obuhvata kako emocionalnu tako i racionalnu (filozofsko-antropološku) stranu ljudskoga bića, čovekovoga ja. U Proljećima Ivana Galeba glavni junak, osvrćući se na detinjstvo, na nekolikim mestima daje viđenje dečijeg doživljaja života i smrti, na osnovu sopstvenog i opšteg iskustva: polazeći od uverenja brojnih religija i filozofija o beskrajnosti i besmrtnosti čovekove duše, Galeb ističe za njega začudnu činjenicu da (u njima) ne postoji razmišljanje o posebnosti dečijeg bića, iskazanom u stavu da dete ima beskrajnu i besmrtnu dušu, koju kasnije, kad odraste, izgubi. ${ }^{11}$ Navedeno polazište razvija se u svojevrsnu raspravu o umiranju drugog i o sopstvenom skončanju, koja podrazumeva razliku između vanvremenog i neuništivog, besmrtnog ja, i spoljašnjeg i efemernog, ,širokog, prostranog, nebrojenog ne-ja koje naspram nama i svud oko nas stoji baš kao i smrt". ${ }^{12} \mathrm{Na}$ taj način spoljašnji, fizički prostor-vreme i njemu pripadajuće telo određuju se kao domen $s m r t i ;{ }^{13}$ sa druge strane, budući da je jastvo

10 Navedena književna tradicija u istoriji evropske književnosti podrazumeva nedovršenost / otvorenost forme, uključivanje mnoštva drugih kako književnih (proznih i poetskih) tako i neknjiževnih oblika. Odricanje od stilskog jedinstva književne vrste ili dela dovodi i do prisutnosti više stilova i glasova u njima (spoj uzvišenog i prizemnog, ozbiljnog i smešnog, korišćenje „pristupnih“ žanrova - pisama, otkrivenih rukopisa, parodija na visoke žanrove, parodijski preosmišljenih citata; mešavina proznog govora i stiha, uvođenje živih dijalekata i žargona, pojava najrazličitijih autorskih maski). Pored toga, polazna tačka ocene i oblikovanja stvarnosti u njima jeste sadašnjost, područje ovovremenog, neposrednog, ponekad i grubo prisnog kontakta sa živim savremenicima (često kroz ismevanje i izrugivanje). Oslanjajući se na iskustvo, ponekad i slobodno maštanje ili filosofsku inspiraciju, žanrovi ozbiljno-smešnog razvijaju duboko kritičan, ponekad i cinično razgolićujući odnos prema predanju, ideološkim dogmama i prema savremenosti, spajajući potragu za istinom sa narušavanjem društvenih i jezičkih konvencija, kroz scene skandala, ekscentričnog ponašanja, neumesne govore i ispade; oštre kontraste i oksimoronske spojeve, nagle prelaze i promene, smenjivanje uzvišenog i prizemnog, čovekovih uzleta i padova. Videti: Mihail Bahtin, Problemi poetike Dostojevskog, Beograd 1967., 169-170.

11 V. Desnica, Proljeća Ivana Galeba, 47. Pri tome Galeb / Desnica u svom razmišljanju provlači malu logičku omašku: ako odrasli čovek gubi besmrtnu dušu koju je imao kao dete, ona je u navedenom slučaju jednostavno privremena i potrošna, i, kao takva, ne zadovoljava polaznu pretpostavku. Hotimično ili slučajno prelaženje preko protivurečnosti prisutno je i na drugim mestima u romanu, naročito u poglavlju o athanatiku, gde uzbudljivost i zaraznost priče potiskuje razmišljanje o krajnjim posledicama iznesenog.

12 „Naše ja sastoji se iz golog fakta bivstvovanja i iz primarnog, slijepog osjećaja tog bivstvovanja." Isto, 286.

13 Kod Lisjena iz Bente-Guštera prisutno je razmišljanje o spoljašnjem materijalnim svetu kao mrtvom: „(...) milioni tona mrtve materije koji mehanički uništavaju milijarde tona druge mrtve materije. Njegovom je umu bila bliža, i punija draži, pomisao kako jedan mali, neznatni, skroz nematerijalni pomak u ljudskoj misli ili u ljudskoj psihi izaziva ogromne učinke u brdima inertne materije vanjskog fizičkog svijeta." Vladan DesniCA, „Benta-gušter“, 
takođe i vanvremeno (,ja nema dobi“), ${ }^{14}$ vremenska dimenzija (lične) prošlosti (ali i „neizvesne" budućnosti) takođe potpada pod istu oblast, što Desnica tematizuje na drugom mestu, prožimajući, u pesmi Kairos, vremensko-prostorne i telesne aspekte: „Dragocjen si, o času sadašnji! / U raspadnutom tijelu vremena / što pružilo se sivim prostorom / ti jedina si živa ćelija. Sve što nisi ti, / ne postoji. / Ti si bljesak svijetla / u tamninama. (...) Jučerašnji moj ja je meni stran, / i dušmanin, / i jezivo me gleda svojim mrtvim očima. / A moje se živo srce seli bez kraja / iz umrloga ja u živo, današnje. / Odatle moja grozničava žurba, / odatle moja žeđ nezajazna!“15

Vrsta opozicije prošlost / sadašnjost (odnosno dete / odrasla osoba) sprovodi se upravo u slučaju dveju epizoda iz Proljeća, kroz reakciju devojčice na smrt bake naspram obrnute situacije u kojoj ista devojčica, sada kao odrasla, smrtno bolesna leži u bolnici. U prvom slučaju, intenzivno ali kratkotrajno, ona oponaša majčinu reakciju - orošenog čela i ulepljene kose plače i stisnutom šačicom rastrljava suze po licu, da bi se nekoliko trenutaka kasnije zaigrala, i u čudu gledala majčinu žalost: „Što plačeš? Ta nije umro Bog!"“16 Ovo (dečije) unutrašnje neshvatanje smrti drugog, iskazano patvorenim i privremenim spoljašnjim iskazivanjem žaljenja, dobija pandan u potonjem vremensko-prostornom aspektu sopstvene smrti. „Pregažena“ životom, bivša devojčica umire od raka utrobe, pri čemu su lekari odstranili sve što se iz nje moglo odstraniti; ono što ostaje predstavlja samo puku koru. ${ }^{17}$ Narušavanje granica između ljudskog tela i spoljašnjeg prostora tako se u očima pripovedača javlja kao siguran znak blizine smrti: osim prodiranja prostora u telo (oči - rupe; telo - šupljina) kod Desnice to važi i za kretanje u obrnutom smeru - za (hiperbolisano) širenje tela u prostor, karakteristično za terminalne stadijume bolesti. ${ }^{18}$

Motiv rasprostiranja tela kao znak smrti sreće se i u duševnom domenu - razmišljanje o beskrajnosti prostora i bezbrojnosti svetova kod deteta izaziva strah od razdvajanja ličnosti, praćen željom za dejstvom grube fizičke sile koja bi ličnost zadržala na okupu. ${ }^{19} \mathrm{Ta}$ sila, koja u Proljećima Ivana Galeba sprečava telo da se rasprostre izvan svojih granica, i razdvoji, u Zimskom ljetovanju prisutna je u razornoj spoljašnjoj fizičkoj snazi obrnutog dejstva, koja rasparčava telo u prostor(u) bombardovanjem, proizvodeći „rasporene utrobe, otrgnute udove, raskoljene lubanje“ odnosno „raskasapljena tjelesa“, ${ }^{20}$ groteskne slike poput

Pripovijetke (= Sabrana djela Vladana Desnice, knj. III), Zagreb 1974., 364. Ovakav postupak ospoljašnjenja duševnog prisutan je i u drugim prilikama tematizovanja (dečijeg) doživljaja sveta, vremena i prostora, u kome se odigrava naročita vitalizacija, u kojoj svaka „mrtva stvar oko mene dobijala je tada živo srce i u njoj su damari odbrojavali časove nepovratnog“. Bez tog specifičnog oživljavanja, spoljašnji, fizički vreme-prostor i telo beznadežno su obeleženi kao područje smrti.

14 V. Desnica, Proljeća Ivana Galeba, 285.

15 Vladan Desnica, „Kairos“, Zimsko ljetovanje. Pjesme. Ljestve Jakovljeve (= Sabrana djela Vladana Desnice, knj. I), Zagreb 1974., 228-229.

16 V. Desnica, Proljeća Ivana Galeba, 48. „Dva crno zaobručena oka ležala su kao dvije rupe u jastuku. Gledao sam je kao šupalj dud, ulište klica smrti. Eto, i nekadašnja plava djevojčica sa suncem u kosi sada je postala samo jedno drago, ubogo, pregaženo ne-ja!" Isto, 49. „Naše iznureno tijelo na bijelim kolicima, već nabuhlo gasovima smrti, bit će sve što postoji; ono će rasti i rasti, nadimat se do visokoga svoda, prerastati granice svijeta, granice svemira." Isto, 193.

19 „Nejako tijelo svo je drhtalo. Slabila je sila što drži na okupu njegovu cjelokupnost, udovi su htjeli da se raspu i rasture. Čitavo je biće stremilo da sobom, kao laganim prorijetkim plinom, ispuni prostor. I taj je poriv rastvaranja, razdvajanja ličnosti bio tako snažan i tako stvaran, da sam osjećao potrebu da me neka gruba i slijepa fizička sila spolja sa svih strana pritisne, da me zgrune, da me suzbije natrag u granice tijela." Isto, 46. 
nemačkog vojnika koji, ravno presečen preko pasa, sa desnom rukom podignutom uvis, kao da harangira ili doziva, s ustima otvorenim kao u kriku, nalikuje na prevaljenu bistu. Do rasparčavanja tela, međutim, dolazi i na druge načine: dok Desnica u vezi sa bolešću (rakom) po pravilu upotrebljava metaforu rasta / nadimanja, u jednom slučaju humorno personifikuje i antropomorfizuje bolesti, objašnjavajući njihov „džentlmenski sporazum“, koji podrazumeva red(osled) nastupanja „sa viljuškom“ ${ }^{21}$ Metaforično izjedanje tela svoj konkretni oblik dobija u motivima doslovnog jedenja / proždiranja, takođe datih u inverznom paru: u Zimskom ljetovanju najpre se sreće naglašeno groteskna slika koja obuhvata emocionalne reakcije deteta / odrasle osobe prilikom jedenja mesa (delova tela) domaćih životinja koje su im neposredno poznate. ${ }^{22}$ Stepen najvišeg užasa u navedenom romanu dostignut je upravo obrnutom situacijom u kojoj krmak Migud - takođe slasno - pred užasnutom majkom - proždire malu Mafaldu / Špižmicu, komadajući pre svega njeno lice. ${ }^{23} \mathrm{U}$ drugoj verziji romana (Beograd, 1957) ovaj je opis, međutim, značajno prerađen i skraćen, sa potpunim izostankom drastičnih detalja; posredno, i ova izmena može se dovesti u vezu sa razmišljanjima o smrti, osvrtanjem na Desničine oglede: iako se, naime, u esejističkim spisima praktično ni na jednom mestu ne razvija tanatološka problematika, upravo igra neraskidivo povezanih suprotnosti života i smrti baca svetlo na njegovo određenje književnog detalja, ${ }^{24}$ time i na (moguću) prirodu intervencije u tekstu Zimskog ljetovanja.

Vratimo se ponovo odnosu smrti i prostora. Pored psihološkog i fizičkog, u tanatopoetičku igru Desnica uvodi i društveni prostor: ako je, sa stanovišta (samo)svesnog / spoznajnog subjekta, smrt sopstvenog bića, kao male tačke svesti okružene beskrajem ništavila, za

21 Tako „u internom saobraćaju među bolestima postoji gentlemen's agreement. Tu nema otimačine ni presizanja. Možda tek izuzetno neka nova, nevaspitana bolest, koja još ne poznaje pravila igre, zaleti se preko reda sa svojom viljuškom. Ali je odmah klopnu po nadlanici.“V . Desnica, Proljeća Ivana Galeba, 259.

22 „Svi znamo očajni vrisak djeteta kad dozna da je batak koji gricka batak njegove drage, prijateljske kokice Pirke; znamo kako se grčevito tada stisne grlo te više nikako ne može da guta.

A slično je i s odraslima. Jer ako nam se, dok slasno jedemo hladetinu, najednom iz ljigave mase promoli ona čisto ljudska trepavica i ispod nje virne u nas, s hladnim prijekorom, ono mrtvo, već bestrasno oko, kao da kaže: 'eh, ljudi, to li vi dakle učiniste od mene!' - zaludu, to je kadro da obeshrabri, to je kadro da olabavi viljušku u ruci. “V. DEsNiCA, Zimsko ljetovanje, 57.

23 „Dirnuta kao nekim predosjećajem (- tako joj se bar kasnije činilo -), Lisetta pograbi tek uzavreo lončić i pohita $\mathrm{k}$ prozorčetu. Krmak je slasno mljackao podigavši gubicu da mu ne bi ispao kakav komadić iz žvala, i treskao glavom kako bi pomogao oklizanje samljevene hrane u grlo; gledao je ravnodušno u Lisettu. Na rubu žvala bio mu je rumenkast trag. Tek onda pogled joj pade na kolica. Uhvati letimičnu sliku: djetetu je falilo pola lica, s okom i komadom čela; na izmusanom okovratniku rub od blijede krvi i pjenaste sline u kojoj je bilo slijepljeno nekoliko šiljatih ječmenih zrna.

Ruke joj se zaletiše u kosu, i samo što začu oštar krik - svoj vlastiti krik ali dalek i tuđi.“ Isto, 192-193.

24 „Pitanje je (stvar je), dakle, naprosto u ovom i jedino u ovom: da li ti takozvani 'detalji' nešto grade, da li nam pisacumjetnik sredstvom tih detalja oblikuje pred očima žive, u sebi logične, kongruentne ljudske likove, da li nam vjerno i živo predočava atmosferu, sredinu, životni ritam, da li nam uspjelo slika i prikazuje sklop života, odnose itd. koje je uzeo za predmet svog djela; da li se, nadalje, sva ta živa materija kreće usmjerena onom cilju koji je (više ili manje svjesno) ležao u namjerama pisca; i da li je - last not least - pisac sve to uspio da učini na dovoljno zanimljiv način.“ Vladan DesnicA, „Dva kratka eseja: 'Marginalije o iracionalnom' i 'Zloupotreba jednog termina: detalj“, Eseji, članci, pogledi (= Izabrana dela Vladana Desnice, knj. IV), Beograd 1993., 150-151. Desnica ovde pet puta upotrebljava poliptotonsko-paregmenonske varijacije reči sa korenom „Živ-“ („žive“; „Života“, „Životni“; „živa“, „Živo“), jasno određujući (uspeli) književni detalj u vitalističkim terminima. Shodno tome, u svetlu opozicije i inverzije prisutne u Desničinim pogledima, može se pretpostaviti da neuspeli detalj, koji ne zadovoljava ove preduslove, predstavlja suprotnost, odnosno - da je (estetički) mrtav. Stoga je samokritička intervencija jedan od mogućih razloga za skraćivanje / ublažavanje opisa Špižmicine pogibije: razvijanje detetove smrti do drastičnih detalja estetski je neuspelo 
Desnicu zapravo smrt celoga sveta / svega što postoji („umrlo sâmō načelo postojanja“), ${ }^{25}$ a smrt drugoga nestanak tek jedne jedinke, sa stanovišta društvene zajednice smrt pojedinca izdvojenog u četiri zida njegove sobe predstavlja samotnu stvar („sitna, privatna smrt“). ${ }^{26}$ Smrt drugog, u očima ljudi iz okruženja, proizvodi paralelni svet mnjenja: (ne)znanje (lažne ili istinite) vesti vezane za smrt pojedinca dovodi do posledica u stvarnosti društvenog okruženja, kako pravoj tako i virtuelnoj - umišljena smrt šjor Karla u Zimskom ljetovanju uzrokuje u zadranskom zbegu paralelnu, do najsitnijih tančina razvijenu spekulativnu realnost (malograđanskog) javnog mnjenja, kao što, u umetnutoj pripoveci iz Proljeća Ivana Galeba, zajednica, svesna stvarne pogibije dečaka, izbegava da majci saopšti vest o smrti njenog sina, uljuljkujući je izmišljenim opravdanjima u lažni spokoj i nadu, i istovremeno posmatrajući, sa (licemernim) sažaljenjem, čuđenjem i osudom, njeno nepromenjeno svakodnevno ponašanje.

Sa druge strane, ,aktivno“ umiranje u okruženju drugih ljudi, nehotično ili hotimično - poput samoubistva učinjenog pred svedocima, ${ }^{27}$ ili junačke / ,junačke" pogibije u ratu ili u atentatu - predstavlja delatnu ,javnu“ smrt, posledicu neke vrste činjenja osobe. Razmišljanja, u velikoj meri ironična, o privatnoj i javnoj smrti, odnosno o istoriji (smrti) jakih pojedinaca naspram „povjesnica čovječanstva“ - istorije „slabih“ ljudi, vode do razmišljanja o političkoj povesti naroda, u kojoj se kao osnovno pitanje javlja odnos vlasti i građana, države i naroda. Upravo uverenje o doglednom odumiranju države, koje priziva i upitanost o odumiranju samih podanika, uvodi „digresivnu“ pripovest (naj)višeg društvenog nivoa, „nedovršeni roman“ o pronalasku leka za smrt - athanatika. ${ }^{28}$

U navedenom delu Desnica polazi od motiva rešavanja problema ljudske konačnosti putem primene naučnih (medicinsko-farmaceutskih) znanja, tematizujući najširi raspon mogućih posledica koje besmrtnost može da ima na ljudsko društvo. Ovakav pristup razrešenju najvećeg, i praktično jedino preostalog, pitanja „u jednoj fantastičnoj zemlji u kojoj su već prethodno svi socijalni, ekonomski i slični problemi riješeni, sve nejednakosti ukinute a bijeda obješena u klin“, ${ }^{29}$ podveden pod opštu borbu dobra i zla, već je unekoliko najavljen u karakterizaciji šjor Karlovog lika u Zimskom ljetovanju, kroz predsta-

- mrtvo - i stoga je uklonjeno. Drugi razlog, međutim, može biti mnogo prozaičniji: upravo je izdvajanje prizora smrti devojčice često prisutno u (negativnim) kritičkim prikazima ovog romana. Pomenuta scena doživljava se kao filmski verna, međutim sa primedbom da je odraz užasa u ljudima veoma bled i nevešto oblikovan. Videti: Živko Jeličić, „Zimsko ljetovanje Vladana Desnice“, Hrvatsko kolo, 3/1950., br. 2, 551.

V. Desnica, Proljeća Ivana Galeba, 48.

26 Isto, 245.

27 „I, jednoga dana - skočio je. U prijepodnevne sate, oko deset i po. I to baš na ulicu a ne u dvorište. Nikome na glavu, ali opet među prolaznike. Valjda iz nagona da ipak nekako obilježi, da ipak nečim podvuče svoju smrt; da ona ne bude baš sasvim neznatna, sasvim nezapažena. Da ipak saljude zainteresira, kointeresira, za se i za nju.“ Isto, 87.

Već samo posredovanje kroz razgovor pripovedača sa nekim „paranoidnim pričalom“, „krezubavim vjetrogonjom“ koji neprestano izlazi „sa novim zamislima i planovima“ (Isto, 237) diskvalifikuje potencijalnu intelektualnu i umetničku vrednost dela i svrstava ga u „niže“ žanrove. Beleške nesuđenog romanopisca služe kao izvor za izlaganje osnovnih postavki fantastičnog proznog ostvarenja u nastajanju; samostalna verzija naslovljena Pronalazak Athanatika, tj. „nedovršeni roman“ o skicama i beleškama, od nekoliko listova, za nenapisani roman koji bi trebalo da obuhvati negde oko 800 stranica, pri tome je znatno većeg obima od poglavlja u Proljećima i sadrži i mnogo više izrazito neuobičajenih ideja i teorija. Objavljena je posthumno u: Vladan Desnica, Proljeća Ivana Galeba. Pronalazak Athanatika (= Sabrana djela Vladana Desnice, knj. II), Zagreb 1975., 349-406. 


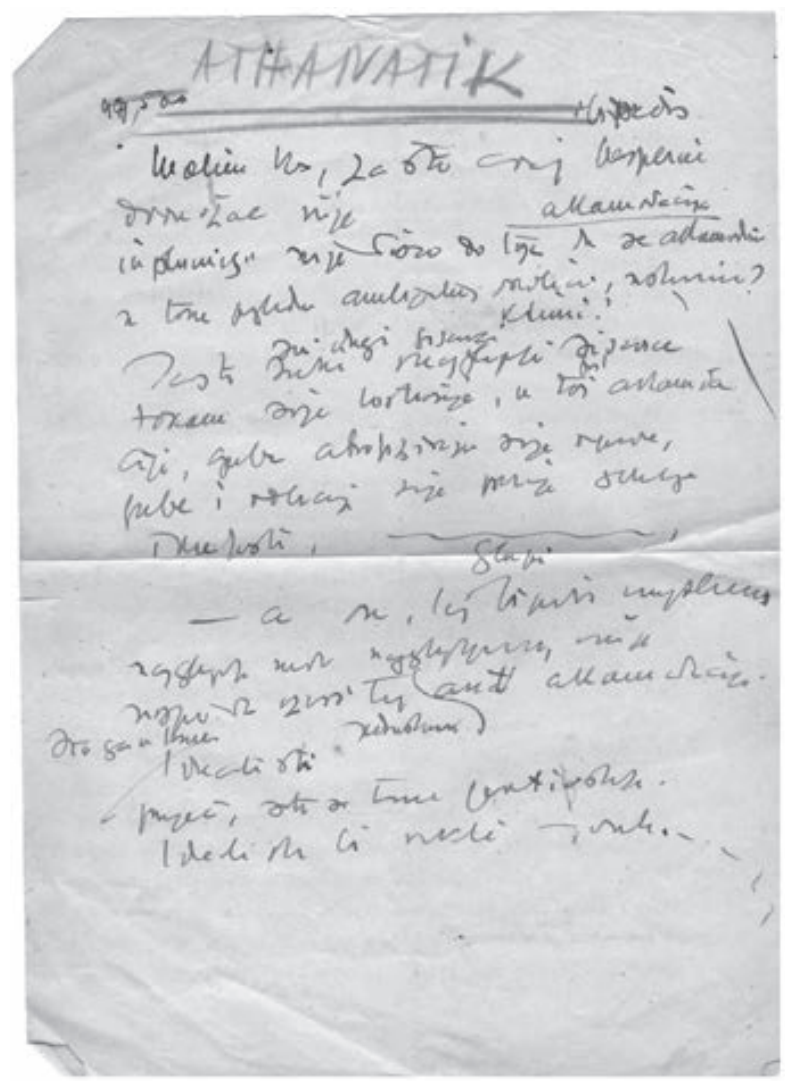

Sl. 1. Fragment autografa romana Pronalazak Athanatika

$\mathrm{vu}$ „naučenjački uporne metodičnosti dobra“ u kojoj se „na svakom koraku bolest pobija lijekom". ${ }^{30} \mathrm{U}$ fantastičnoj pripovesti, athanatik u svojoj prvoj verziji $(A)$ predstavlja lek svih lekova - ultimativni medikament, podjednako delotvoran i kod spontane prirodne smrti i kod fatalnog udesa, ubistva i samoubistva. Ostvarivost besmrtnosti, praktično i ljudske neuništivosti, međutim, iz temelja menja međuljudske odnose - pre svega, primena i raspodela leka služe kao instrument moći i temelj nove, najviše diskriminacije među ljudima: nejednakosti pred smrću. Stvorena je pravna ustanova „Izuzeća od smrti“ (nem. Todesenthebung); nimalo neočekivano, utvrđivanje „socijalne dužnosti življenja“ proteže se, počev od vladara države, preko ministara, sudija, akademika, do najnižih slojeva državnog činovničkog aparata. Sa druge strane, selektivna raspodela uzrokuje (veštačke) nestašice i krivotvorenja kako leka tako i Todesenthebung-a, i stvaranje razvijene mreže crnoberzijanstva i šverca; u takvom okruženju plava devojčica sa „suncem u kosi“ dobija u Athanatiku još jedan groteskni inverzni odraz - društveni pandan u obliku kolektivnog subjekta, i doslovno i prenosno podzemnog, neposredno uključenog u nezakonitu raspodelu leka, koji priziva drastične slike snižavanja i animalnih poređenja (štakori; čopori koji skviče „kao mali šakali“). ${ }^{31}$

Nemogućnost oduzimanja života tokom kratkog razdoblja postojanja i raspoloživosti athanatika $A$, koji ne samo što zaustavlja starenje, nego i razvija otpornost na povrede, ima za posledicu obesmišljavanje najtežih kazni. Smrt streljanjem na licu mesta zbog nezakonitog posedovanja leka postaje stoga farsično besmislena u odnosu na mučnu tematizaciju kritičnog trenutka pogubljenja u Desničinoj pripoveci Pred zoru. Dok četnički simpatizer

30 V. Desnica, Zimsko ljetovanje, 133.

31 Šverc ampulica „najviše se širio putem dobro organizovane podzemne mreže ženske djece. Dočekivale su vas iza ugla djevojčice crnih zuba, od dvanaest, od deset, od osam godina, i odvlačile vas za rukav ružno namigujući. Poveli su veliku hajku na te štakore iz podzemlja. Opkolili bi kvart, spuštali policijske pse u vodove kanalizacije i istjerivali čitave čopore djevojčica koje su skvičale kao mali šakali. Neke su se branile da to čine radi iznurenih očeva na samrtničkoj postelji. Po gradovima u unutrašnjosti bilo je slučajeva da su ih na buljuke izvodili pred zidove i likvidirali mitraljezima. Ali sve to nije mnogo pomoglo." V. Desnica, Proljeća Ivana Galeba, 260. 
Bogdan, čekajući streljanje, proživljava užas poslednjih trenutaka života, maštajući da se od spoljašnje propasti sakrije u utrobi drugog živog bića, ${ }^{32}$ besmrtni i neuništivi posedovalac athanatika, izjednačen sa veleizdajnikom, ima sasvim drugačiji, drsko-bezbrižni pristup i doživljaj pogubljenja. ${ }^{33}$ Desnica tako razvija antiutopijsku / distopijsku viziju najrazličitijih zloupotreba i negativnih posledica leka protiv smrti, protkanu humornom notom u rasponu blage do sardonične ironije, preobraćajući uobičajeni odnos prema umiranju, ali i izvodeći (opet prividno) dosledno posledice - pronalazak athanatika, čak i kada je zamenjen drugom, „poboljšanom verzijom“, athanatikom $B$, delatnom samo kod prirodne smrti, dovodi do potpunog izvitoperenja međuljudskih odnosa $\mathrm{i}$ - kroz bujanje totalitarizma i izbijanje sveopštog nemilosrdnog rata - do propasti društtvenih struktura, preteći da na kraju potpuno uništi ljudsku civilizaciju. ${ }^{34}$

Sa izglednom propašću država i naroda, krajnji nivo razrešenja problema besmrtnosti na taj se način poverava naddržavnom telu, $u$ kome su zastupljene i angažovane sve zemlje i nacije, i koje predstavlja samo čovečanstvo. Na kraju, paradoksalno, na osnovu sveopšteg zahteva populacije („VRATITE NAM NAŠ RAK! VRATITE NAM NAŠU SMRT!“), ${ }^{35}$ dolazi se do svesti o neophodnosti uništenja athanatika i o izvornom, osnovnom, neotuđivom pravu čoveka na bolest i umiranje - neprirodno produžena čovekova egzistencija na taj se način pokazuje kao bolest na smrt, a lek za nju predstavlja upravo smrt sâma.

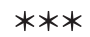

Već i provizorni pokušaj razmatranja načina na koje se u stvaralaštvu Vladana Desnice razlaže i razvija tanatološka problematika pokazuje da se može govoriti ako ne o svojevrsnoj opsednutosti temom smrti onda o njenom nesumnjivom obuhvatnom i temeljnom prisustvu u Desničinom književnom delu. Raznolikost razvijanja problematike smrt(nost)i, umiranja, pogrebenja, nasilnog i prirodnog životnog kraja, samoubistva, bolesti i mogućnosti

32 „U Bogdanu sve prenaglo splasnu, skljoka se tako nisko da više iz njega ne vrisnu ni očaj ni pobuna - činilo mu se da evo kroči u smrt već po treći, po četvrti put. Iz nedaleka grma ispade do po trupa krava meljući utrgnutu grančicu: zastala, uprla mirne oči i vlažnu njušku u grupu ljudi. Bogdan je spazi; iz pomirene pregorenosti laznu očajno želja za životom: osjeti silnu, neodoljivu privlačnost prema toj kravi - ujedno i zavist i nostalgiju -, zaželi svom snagom da mu je uteći u nju, skriti se u mračnoj i dobroj toploti njene nutrine, i poživjeti tako, slijepo i zaštićeno, bez kraja i konca... Vojnici ga privedu k hrastu, odstupe nekoliko koraka i podignu puške. Gluha lupa srca u njemu stade da buja, buja, da prerasta van njega, da mu odjekuje bolno u ušima, zaglušujući i zamagljujući sve uokolo, i zvukove, i slike, i misli. I kad grunu plotun, njemu se učini da dopire s nekog drugog svijeta, i da to ne puca u nj već u njegovu praznu košulju.“"Vladan Desnica, „Pred zoru“, Pripovetke, Beograd 1993., 272.

33 „Fućkam ja na strijeljanje', govorio je čovjek odlazeći na stratište, 'ako sam prethodno primio moju ampulicu Athanatika!' Više-manje, rupa na leđima kaputa bila je sva šteta. Zato su u tom periodu radnje za umjetno krpljenje nicale kao gljive poslije kiše. Strijeljani bi se potajao, noću ustao od mrtvih, u prvoj radnji zakrpio rupu na leđima, pa zviždućući odšvrljao u mjesto gdje ga ne poznaju." V . Desnica, Proljeća Ivana Galeba, 265-266.

34 „U pojedinim zemljama buknule su revolucije. Ljudi su provalili iz svojih kaveza, iz svojih brloga i jazbina, mračni, crni u licu, žedni krvi. Kroz masu je provrvjela praznovjerica da krv besmrtnih produžuje život smrtnima. Po ulicama ste mogli vidjeti rojeve kosmatih smrtnika sakupljenih oko lešine kakvoga besmrtnika: na koljenima, pobožno su joj sisali krv ispod grla..." V. Desnica, Proljeća Ivana Galeba, 249. I potom: „Odigravali su se neopisivo krvavi prizori. (...) Zaređale su masovne egzekucije, u industrijskom opsegu. Stupili su u akciju i bojni otrovi. Unutrašnjost je bombardirana iz specijalnih aviona kratkog radijusa, za domaću upotrebu. Ponegdje su osposobljene i stare gasne komore iz ranijih vremena..." Isto, 251.

35 Isto, 268. 
lečenja i iskorenjivanja (smrtonosnih) oboljenja, odnosa prema mrtvima - sa psihološkog, filozofskog, sociološkog, ili, pak, medicinsko-farmaceutskog stanovišta - svedoči o širini Desničinog promišljanja i raznovrsnosti poimanja problema skončanja. Pri tome, smrt kod Desnice nikada nije samostalna ili samo(za)dovoljna tema, već podrazumeva i relativizovanje, dovođenje u vezu sa širim piščevim pogledima na egzistenciju odnosno (ljudsku) stvarnost u celini, podrazumevajući tu i specifična estetička shvatanja.

Učestalost i zastupljenost tematizacija smrti u praktično svim vidovima i oblastima Desničinog stvaralaštva (naslovi, lokalni motivi u poeziji i prozi, tematske okosnice pojedinih dela, psihološka motivacija likova, predmet rasprava, estetičko-poetički uticaj, činjenica par excellence itd.) svedoče o tome da su tanatološka pitanja nezaobilazni strukturni činilac opusa. Razmatrajući, dalje, odgovarajuće književno modelovanje motiva vezanih za smrt, pokazuje se da su kod Desnice oni po pravilu uobličeni na brojne i različite načine, pri čemu se istovetni motivi drugačije razvijaju u zavisnosti od okolnosti, ${ }^{36}$ ili se pak u različitim situacijama uočava istovetni model oblikovanja / argumentacije, čime se uspostavlja izrazita raznolikost umetničkih postupaka odnosno ističe njihova funkcionalna uslovljenost. ${ }^{37}$

$\mathrm{Na}$ širem planu, zastupljenost i razvijanje problematike smrti kod Desnice osvetljava naročite književne postupke i žanrovske izbore (spajanje motiva vezanih za smrt sa nizovima ideja, slika i postupaka koji deluju u najmanju ruku neočekivano ili neobično, katkada i šokantno - groteskno prikazivanje tela, njegovo komadanje ili jedenje / proždiranje, smrt praćena šalom i smehom, pervertirana seksualnost; otvorenost i nedovršenost dela; polifono spajanje romana sa esejistikom, poezije sa prozom, pustolovine sa apstraktnim razmišljanjem; eksplicitne sa implicitnom poetikom, uz umetanje manjih žanrova - solilokvija, dijaloga, ispovesti, priče, pesme, itd. - u veće). Ovakva osobenost nalaže da se u mnogobrojnim Desničinim tematizacijama smrti, i sa njima uže i šire povezanim motivima, potraži dejstvo poetičkih načela koja, osim utemeljenosti u ličnoj poetici, podrazumevaju i određenu „višu logiku“ - upliv opštijih književnoumetničkih modela odnosno tradicija, vezanih pre svega za istoriju žanrova „ozbiljno-smešne“ / karnevalizovane književnosti evropskog kulturnog prostora.

Navedene optike stapaju se u posebnu višedimenzionalnu, „multiskopsku“ sliku Desničinih tanatologija koje, prožimajući se sa poetikom, prerastaju u svojevrsne stvaralačke tanatologike. Stoga ove naročite igre poetike i smrti mogu predstavljati jedan od ključeva za obuhvatno i slojevito tumačenje Desničinog književnog opusa.

\footnotetext{
$\overline{36}$ Poput pogubljenja streljanjem; način oblikovanja često zavisi i od društvene odnosno rodne pripadnosti likova, kao kod motiva (samo)ubistva.

37 V. Biti, Doba svjedočenja, 160-161.
} 


\section{$\cos$}

\section{Izvori i literatura}

\section{Izvori}

Vladan Desnica, Eseji, članci, pogledi (= Izabrana dela Vladana Desnice, knj. IV), Beograd 1993.

Vladan DesnicA, „Gadni mali gnom“, Republika, 64/2008., br. 3-4, 3-21.

Vladan Desnica, „Nobelovac“, Ilustrirani vjesnik (Zagreb), br. 184, 5. 3. 1949., 12.

Vladan Desnica, Pripovetke, Beograd 1993.

Vladan Desnica, Pripovijetke (= Sabrana djela Vladana Desnice, knj. III), Zagreb 1974.

Vladan Desnica, Proljeća Ivana Galeba, Beograd 1982.

Vladan Desnica, Proljeća Ivana Galeba. Pronalazak Athanatika (= Sabrana djela Vladana Desnice, knj. II), Zagreb 1975.

Vladan Desnica, „Spiriti“, Književnost, 9/1954., br. 7-8, 78-79.

Vladan Desnica, Zimsko ljetovanje, Zagreb 1950.

Vladan Desnica, Zimsko ljetovanje. Pjesme. Ljestve Jakovljeve (= Sabrana djela Vladana Desnice, knj. I), Zagreb 1974.

\section{Literatura}

Mihail Bahtin, Problemi poetike Dostojevskog, Beograd 1967.

Vladimir Biti, Doba svjedočenja. Tvorba identiteta u suvremenoj hrvatskoj prozi, Zagreb 2005.

Živko Jeličıć, „Zimsko ljetovanje Vladana Desnice“, Hrvatsko kolo, 3/1950., br. 2, 551.

Rečnik književnih termina (gl. ur. Dragiša Živković), Beograd 1992.

\section{$\cos$}

\section{VladAN Desnica's THANATOLOgIES - THE GAMES OF POETICS AND DEATH}

The paper examines aspects of the theme-motif complex of disease, dying and death in the work of Vladan Desnica, which addresses such problems as suicide, violent death, the possibility of curing and eradicating disease, and achieving immortality. Desnica's vision of human decay and vanishing raises important issues concerning the nature of human existence on the individual and the collective levels, as well as thought and creation, moral responsibility for one's own death and the deaths of others, even pondering possible solutions to the problem of human finality and the potential impact of immortality on society. The latter produces an anti-utopian vision, with all kinds of abuses and harmful practical consequences of immortality. On the other hand, even though this is not immediately evident in all of his work, that subject matter tends to be accompanied by a wide variety of grotesque motifs, images and ideas, including different kinds of humor. Desnica's treatment of these themes and motifs implies the duality of the high and the low, the notional and the physical, the serious and the humorous or ironic, the harmonious and the grotesque. It also encompasses the the open-endedness and the incompleteness of a work, the polyphonous melding 
of the novel and the essay, of poetry and prose, adventure and abstract thought, as well as explicit with implicit poetics, in addition to inserting smaller genres (soliloquies, dialogues, confessions, stories, poems, etc.), which indicate certain features of seriocomic/carnivalized literature. Therefore, the importance of exploring the genealogical perspective of the humorous and carnivalized approach to the problem of disease and death as one of the possible keys to a comprehensive and multilayered interpretation of Desnica's work.

Key words: Vladan Desnica, the topic of death, seriocomic literature genres, carnivalization, the grotesque 